\title{
The Critique of Hamletism in The Wild Irish Girl and Corinne
}

\author{
Raphaël Ingelbien and Benedicte Seynhaeve
}

D ublished within a year of each other (though without evidence of mutual influence), Sydney Owenson, Lady Morgan's Wild Irish Girl (1806) and Germaine de Staël's Corinne (1807) are in many ways similar, groundbreaking novels that had a considerable impact on the British literary scene. ${ }^{1}$ In both texts the heroine stands for a misunderstood or oppressed nation, while the male protagonist represents a superior power (Britain) that is invited to discover and do justice to a supposedly inferior country (Ireland, Italy). The personalities and liberal politics of the writers, who are partly mirrored in their heroines, are also similar, and indeed Staël and Owenson came to appreciate each other. Since the rise of scholarly interest in Owenson in the 199os, The Wild Irish Girl and Corinne have been compared in many discussions of her work. ${ }^{2}$

${ }^{1}$ References to the texts in this article draw on the following editions: Sydney Owenson, Lady Morgan, The Wild Irish Girl: A National Tale, ed. Kathryn Kirkpatrick (Oxford: Oxford University Press, 1999); Germaine de Staël, Corinne ou l'Italie, ed. Simone Balayé (Paris: Gallimard, 1985), in English as Corinne, or Italy, ed. and trans. Sylvia Raphael (Oxford: Oxford University Press, 1998).

${ }^{2}$ For the most recent comparisons between Staël and Owenson see Christopher Nagle, "Traveling Pleasures and Perils of Sensibility," Wordsworth Circle 39, nos. 1-2 (2008): 49-52; and Christina Morin, "Undermining Morality: National Destabilisation in The Wild Irish Girl and Corinne ou l'Italie," in Irish Women Writers: New Critical Perspectives, ed. Elke D'hoker, Raphaël Ingelbien, and Hedwig Schwall (New York:

We would like to thank Marshall Brown, Claire Connolly, and Juliet Shields for comments on different versions of this essay.

Modern Language Quarterly 72:2 (June 2011)

DOI 10.1215/00267929-1161336 @ 2011 by University of Washington 
One common feature that has so far escaped attention is the subversive intertextual dialogue that both novels conduct with Shakespeare's Hamlet or, more specifically, with the cult of Hamlet that emerged in the Romantic period. Besides providing another link between Owenson's and Staël's aesthetics, a comparison of their critiques of Hamletism reveals a shared concern about the appropriation of melancholy by male Romantic intellectuals and its association with conservative or quietist politics.

Deeply influential though they were in their own time (both novels were best sellers in Britain), The Wild Irish Girl and Corinne were afterward sidelined in critical constructions of British Romanticism, which usually emphasized the works of male poets as opposed to female novelists. Renewed attention to the work of Romantic women writers, however, has challenged many dominant narratives about Romanticism. ${ }^{3}$ Owenson's and Staël's dialogues with Hamlet are doubly interesting because both writers attempted to counter the rise of precisely such a dominant narrative by critically engaging with one of the great icons of European Romantic thought.

In the Romantic period Hamlet developed into a figure of identification for the melancholy male intellectual; by the nineteenth century the moody Danish prince had become established as the central character in the Shakespearean canon. The gradual rise of Hamletism, a complex process rooted in late eighteenth-century European culture, has been comprehensively charted elsewhere. ${ }^{4}$ In brief, the character of

Lang, 201 1), 163-78. Cliona Ó Galchoir suggests an early link between the two writers by reading The Wild Irish Girl as a response to arguments developed in Staël's De la littérature ("Germaine de Staël and the Response of Sydney Owenson and Maria Edgeworth to the Act of Union," in France-Ireland: Anatomy of a Relationship; Studies in History, Literature and Politics, ed. Eamon Maher and Grace Neville [Frankfurt am Main: Lang, 2004], 69-82).

${ }^{3}$ See, e.g., Carol Shiner Wilson and Joel Haefner, eds., Re-visioning Romanticism: British Women Writers, I776-I837 (Philadelphia: University of Pennsylvania Press, 1994); Paula R. Feldman and Theresa M. Kelley, eds., Romantic Women Writers: Voices and Countervoices (Hanover, NH: University Press of New England, 1995); and Anne K. Mellor, Mothers of the Nation: Women's Political Writing in England, I780-1830 (Bloomington: Indiana University Press, 2000).

4 See, e.g., R. A. Foakes, "The Reception of Hamlet," Shakespeare Survey 45 (1992): 1-13; Margreta de Grazia, "Hamlet before Its Time," MLQ 62, no. 4 (2001): 355-75; Alexander Welsh, Hamlet in His Modern Guises (Princeton, NJ: Princeton University 
Hamlet was gradually extricated from the dramatic context of Shakespeare's play, and emphasis was laid on the protagonist's psychology as a determinant of tragic action — or, in Hamlet's case, of a perceived lack of action. As Hamlet's name grew into a synonym for morbid introspection, his melancholy was lifted from the realm of humoral theory, was divested of eighteenth-century connotations that associated it with the English national character, and became an individual expression of Romantic weltschmerz. ${ }^{5}$ Crucially, Hamlet's irresolution became a mirror of the ideological crisis that affected many European intellectuals after the excesses and eventual failures of the French Revolution. At the end of that process, the Romantic Hamlet was fully formed and defined through the now-familiar diagnoses by Goethe's Wilhelm Meister and by Samuel Taylor Coleridge: Hamlet was "a fine, pure, noble and highly moral person, but devoid of that emotional strength that characterizes a hero."6 The Prince of Denmark was a hypersensitive creature, a schöne Seele, an intellectual characterized by "great enormous intellectual activity, and a consequent proportionate aversion to real action," a pathologically irresolute procrastinator, a tragic hero who could not make up his mind. ${ }^{7}$ As such, he helped many Romantic intellectuals voice a postrevolutionary predicament: "The quoting of Hamlet by English critics in the decades after 1789 . . expresses their obsession with political inaction and artistic failure." 8

That Romantic Hamlet is also present in the works of Owenson

Press, 2001); and Marvin W. Hunt, Looking for Hamlet (New York: Palgrave Macmillan, 2007). Foakes largely reserves the term Hamletism for nineteenth-century appropriations of Hamlet; the present article uses the term for tendencies already at work in the late eighteenth century.

5 The Romantic transformation of eighteenth-century melancholy from a national trait and humoral attribute into an individual pathology affecting superior but alienated souls is discussed in Eric Gidal, “'A Gross and Barbarous Composition': Melancholy, National Character, and the Critical Reception of Hamlet in the Eighteenth Century," Studies in Eighteenth-Century Culture 39 (2010): 235-61.

6 Johann Wolfgang von Goethe, Wilhelm Meister's Apprenticeship, ed. and trans. Eric A. Blackall in cooperation with Victor Lange (1989; repr. Princeton, NJ: Princeton University Press, 1995), quoted in Welsh, 74 .

7 Coleridge's Criticism of Shakespeare: A Selection, ed. R. A. Foakes (London: Athlone, 1989), 112.

8 Gary Taylor, Reinventing Shakespeare: A Cultural History from the Restoration to the Present (London: Vintage, 1991), 110. 
and Staël. But far from being purely a model for the self-flagellating intellectual, the Hamlet of The Wild Irish Girl and Corinne encapsulates an attitude that the male protagonist is invited to outgrow - and the challenge is issued in each novel by a woman who, speaking up for an oppressed and misunderstood nation, variously assumes the features of a Shakespearean heroine who serves as a foil to the novel's Hamlet. Instead of participating in the Romantic refashioning of Hamlet, Owenson and Staël challenged Hamletism from within; in so doing, they tried to wrest melancholy and sensibility from their Romantic reductions and to restore them to the more positive roles that both phenomena played in eighteenth-century Enlightenment discourse.

Before exploring Owenson's and Staël's uses of Hamlet, we must stress that while the Irish novelist flaunts her use of the play, Staël employs more muted and implicit allusions. Owenson's notoriously liberal use of literary quotations might call into question the idea that references to Hamlet can be read as a systematic key to her novel. The allusions to many different texts in her work sometimes suggest name-dropping by a combative but insecure novelist with literary pretensions. Yet there is method in The Wild Irish Girl's numerous allusions to Hamlet. ${ }^{9}$ Together, they constitute a coherent response to the play, or to the way that it was increasingly read and staged in England. Although Owenson in 1806 did not know of Coleridge's famous pronouncements or of English translations of Goethe's Wilhelm Meisters Lehrjahre, she would have been familiar with the interpretations and the impersonations of Hamlet that had reshaped the popular view of Shakespeare's protagonist for more than three decades. The "psychologization" of Hamlet had been initiated by various essays in the 1770 ; by 1780 one critic could argue that "the basis of Hamlet's character seems to be an extreme sensibility of mind, apt to be strongly impressed by its situation, and overpowered by the feelings which that situation excites." 10 Since the beginning of

${ }^{9}$ For a reading of Hamletic allusions in The Wild Irish Girl that focuses on the motif of clothing see Julie Donovan, "Text and Textile in The Wild Irish Girl," EireIreland 43, nos. 3-4 (2008): 50-52. Thomas Tracy makes a case for significant allusions to Shakespeare's Henry V in The Wild Irish Girl in Irishness and Womanhood in Nineteenth-Century British Writing (Burlington, VT: Ashgate, 2009), $21-23$.

${ }^{10}$ Quoted in Paul S. Conklin, A History of "Hamlet" Criticism, I6oI-I82I (London: Routledge and Kegan Paul, 1957), 7 o. 
his career in the 1780 s, the actor John Philip Kemble had left his own imprint on the character by giving the role "a meditative, ruminatory, sepulchral cast - a coloring which may well be termed romantic" and which contemporaries commended for its faithfulness to "the weakness and melancholy of Hamlet" (quoted in Conklin, 121-22). As a keen observer of the contemporary literary scene and as the daughter of an itinerant actor, Owenson knew her and others' Hamlet well, and she no doubt understood how the character was being reinvented. ${ }^{11}$

Staël's interest in Shakespeare was that of a formidably erudite writer attuned to European literary developments, including the nascent cult of Shakespeare in Germany and the influential rereading of Hamlet's character proposed in Wilhelm Meisters Lehrjahre, with which she had recently become familiar. ${ }^{12}$ The Shakespearean intertext in Corinne that has understandably received the most attention is Romeo and Juliet, since Corinne's performance of the Italian heroine greatly impresses the protagonist Lord Nelvil, who duly falls in love with her. One critic has called for more attention to the gender politics implied by Staël's choice of Shakespearean intertext, which appears very different from Goethe's. ${ }^{13}$ Hamlet is another strong intertextual presence in Corinne, and Staël's use of the play's gender politics confirms important nuances between Staël's version of Romanticism and the one propounded by Goethe's hero. But comparisons between Lord Nelvil and Hamlet have so far been critically neglected. While Hamlet functions as Owenson's explicit role model, Lord Nelvil's intertextual ancestry is both more covert and more complex; Staël critics have mostly linked

11 Of her family upbringing Owenson wrote: "Shakespeare, Handel, Carolan the Irish Bard . . . were the three Dii Majorum Gentium of our household altars" (quoted in Mary Campbell, Lady Morgan: The Life and Times of Sydney Owenson [London: Pandora, 1988], 22).

12 "Eighteenth-century British commentary on Shakespeare's play had already swung toward character, Hamlet's sensibility and procrastination, and even the suggestion of a hero who fails to be one. But Wilhelm Meister's articulation of the character had the most powerful impact on literary history" (Welsh, 73).

13 As Maddalena Pennacchia observes, "Mme de Staël chooses Romeo and Juliet in order to fashion a sense of Italian identity, while Goethe . . . had envisaged the performance of Hamlet as a way of giving shape to German identity. This is a crucial difference which has many consequences for the issue of romanticism and gender, and which should be further investigated" ("William Shakespeare, Mme de Staël and the Politics of Translation," Folio 13, no. 1 [2006]: 18n21). 
him with the (anti-) hero epitomized by Châteaubriand's René and since then a stock character in French Romantic literature. ${ }^{14}$ By proposing Hamlet as yet another source, the present reading confirms the overdetermined nature of Lord Nelvil, but it also helps situate his melancholy in the broader European context that Staël undoubtedly had in mind when writing her most cosmopolitan novel. Furthermore, this reading highlights the recognition that Hamlet's character had achieved in France, as attested by another keen reader of Shakespeare, Châteaubriand, whose hero René was quickly linked to Hamlet. ${ }^{15}$

Both Staël's and Owenson's protagonists have Shakespearean names: Oswald, Lord Nelvil, and Horatio M., respectively. Oswald and Horatio are of course secondary characters from King Lear and Hamlet. This in itself may already indicate that they are not heroes but inherently passive characters: they are not Prince Hamlet but attendant lords, though this perception is part of the Hamletism that T. S. Eliot's Prufrock anatomized much later (Foakes, "Reception," 1). In their very passivity both characters are remarkably like the Romantic Hamlet-Owenson's protagonist very self-consciously so. Before his meeting with the Irish Glorvina, the young, bored English aristocrat continually analyzes himself in Hamletic terms. Quoting Hamlet's first soliloquy (1.2.133-34), Horatio declares that “'so weary, stale and unprofitable' appear to me the tasteless pleasures of the world I have left, that every sense, every feeling, is in a state of revolt against its sickening joys" (30). ${ }^{16}$ Exiled in Ireland on his father's orders for his youthful antics, the jaded hero explains, "I live in the tomb of my expiring mind, and preserve only the consciousness of my wretched state, without

14 See, e.g., Margaret Waller, The Male Malady: Fictions of Impotence in the French Romantic Novel (New Brunswick, NJ: Rutgers University Press, 1993). Waller's study calls attention to the gendered nature of Romantic melancholy, of which Hamletism is another variant.

15 When the Revue des deux mondes reprinted an extract from Châteaubriand's Essai sur la littérature anglaise, its foreword included a reference to the essential kinship between the two characters: "Face to face, René and Hamlet soon recognized the spark of kinship that their encounter produced" (René et Hamlet, face à face, ont reconnu de bonne heure les éclairs fraternels de leurs fronts) ("Shakespeare," Revue des deux mondes 5 [1836]: 5 ).

16 References to the play draw on Hamlet, ed. Harold Jenkins (1982; repr. London: Thomson Learning, 2001). 
the power, and almost the wish to be otherwise than what I am" (33). The solitude he seeks is also a Hamletic isolation, for in describing it he echoes the prince's speech to Rosencrantz and Guildenstern in 2.2.309-10: "I have, however, neither been visible to the visitants, nor accepted their invitations; for 'man delights not me, nor woman neither'" (33). Horatio's propensity to cast himself as a melancholy Prince Hamlet is challenged once he finds himself a guest of the Prince of Inismore and of his intriguing daughter, Glorvina. Although he does keep up his Hamletic airs on certain occasions, he is increasingly aware of their artifice:

I had just made my toilette, for the first time since my arrival at the castle; and with a black ribbon of the nurse's across my forehead, and silk handkerchief of the priest's supporting my arm, with my own "customary suit of solemn black," tintless cheek, languid eye, and pensive air, I looked indeed as though "melancholy had marked me for her own"; or an excellent personification of "pining atrophy" in its last stage of decline. $(67)$

Mixing Hamlet's self-description in 1.2.78 with an echo of Thomas Gray's "Elegy Written in a Country Churchyard," Horatio inadvertently highlights the cultural transformations that Hamlet's melancholy had undergone since the eighteenth century, but his posturing also reveals Owenson's irritation at the narcissistic withdrawal with which Hamletism was associated. The sense of distance afforded by removal to Ireland and contact with its spokeswoman, Glorvina, allows Horatio to reject the passivity and solipsism of this Romantic Hamlet, for whom no cause has been stirring enough. Discovering "wild" Ireland with the help of his bewitching local cicerone, Horatio is roused to sympathy for a country that formerly existed in his eyes only through the negative stereotypes common among his English contemporaries. His budding love for Glorvina thus coincides with a growing awareness of the wrongs done to her country.

In Corinne Lord Nelvil's melancholy appears more deeply rooted and less self-indulgent than Horatio's. It is, after all, linked to a prolonged state of mourning: Lord Nelvil suffers from "the most poignant grief of all, the loss of a father" (la plus intime de toutes les douleurs, la perte d'un père) $(5 ; 26)$. In Staël criticism, this quotation from the opening paragraph of Corinne has usually been interpreted as a biographical ref- 
erence to the author, who lost her own beloved father in 1805 , one year before she started work on the novel. Necker was certainly a formidable father to have and to lose, and Corinne can indeed be read as part of Staël's own mourning process. ${ }^{17}$ Yet the obstinacy of Lord Nelvil's grief suggests that Staël had Hamlet in mind: Lord Nelvil mourns longer than anyone else, takes offense at those who come to terms with their loss too early, and arouses the suspicion that his own state, like Hamlet's, is less one of bereavement than of pathological melancholy. When Corinne, intrigued by Lord Nelvil's funereal mood, asks the Comte d'Erfeuil "for whom is he wearing mourning?" d'Erfeuil answers, "For his father, Madame . . . although it is more than a year now since he lost him, but as it is natural for us all to survive our parents, I imagine that there is some other hidden reason for his long, deep-seated melancholy" ("De qui porte-t-il le deuil?"-De son père, madame ... quoiqu'il y ait plus d'un an qu'il l'a perdu; et comme la loi de la nature nous oblige tous à survivre à nos parents, $\mathrm{j}$ 'imagine que quelque autre motif secret est la cause de sa longue et profonde mélancolie) $(41 ; 78)$. D'Erfeuil echoes Claudius, who initially tries to cheer Hamlet by invoking "nature ... whose common theme / is death of fathers" (1.2.102-4) and who gradually comes to suspect that "there's something in his soul / O'er which his melancholy sits on brood" (3.1.166-67). Like Hamlet, Lord Nelvil defends his prolonged mourning aggressively: "Did you not see last month, at the theatre, a man who had lost his wife the week before, and a wife he said he loved - you told me so yourself? Here people want to get rid of both the dead and the idea of death as soon as possible" (N'avez-vous pas vu, je le tiens de vous, le mois dernier, au spectacle, un homme qui avait perdu huit jours auparavant sa femme, et une femme qu'il disait aimer? On veut ici se débarrasser, le plus tôt possible, et des morts, et de l'idée de la mort) $\left(97 ; 15^{6}\right)$. He clearly feels betrayed by those who have completed the mourning process: "He saw

17 The impact of Necker's death on Corinne is a recurrent theme in studies of it. See, e.g., Claire Garry-Boussel, Statut et fonction du personnage masculin chez Madame de Staël (Paris: Champion, 2002), 59. Other sources for Lord Nelvil's filial mourning include Châteaubriand's René, who is also profoundly affected by his father's death (see, e.g., Waller, 57). But while René's loss increases an already manifest melancholy, Lord Nelvil's condition develops with the loss of his father. Thus Lord Nelvil arguably has more in common with Hamlet than with René. 
that time had made everyone used to the loss of the man for whom he mourned. The servants no longer felt they had to mention his father's name to him, and everyone had returned to his usual occupations" (Il vit que le temps avait accoutumé tout le monde à la perte de celui qu'il pleurait: les domestiques ne croyaient plus devoir prononcer devant lui le nom de son père; chacun était rentré dans ses occupations habituelles) $(316 ; 464)$.

Beyond his almost pathologically prolonged mourning, Lord Nelvil exhibits the Hamletic attributes of apathy, indecision, and scruples of conscience, all related to a melancholy that he, like Owenson's Horatio, finds it difficult to break out of. Lord Nelvil's likeness to the Romantic Hamlet is evident from comments such as "Mingled with a thousand outstanding virtues there was much weakness and indecisiveness in his character" (Il avait, à travers mille rares qualités, beaucoup de faiblesse et d'irrésolution dans le caractère) $(196 ; 296)$. His defense echoes Hamlet's "Thus conscience does make cowards of us all” (3.1.83): "Do not accuse me of weakness, for courage is powerless against conscience" (Ne m'accusez pas de faiblesse; mais le courage ne peut rien contre la conscience) $(224 ; 336)$. Lord Nelvil's conscience, though, is synonymous with his father's will, which weighs as heavily on his mind as the Ghost's terrible revelation and command, in Wilhelm Meister's reading, weighs on the delicate soul of the Prince of Denmark. Faced with the necessity of giving up Corinne to comply with his late father's wish that he should marry an English woman, Lord Nelvil either longs for death or takes refuge in indecision: "To break Corinne's heart or fail in his duty to his father's memory was such a cruel dilemma that he prayed for death a thousand times in order to escape it. In the end he did again what he had done a thousand times; he postponed the moment of decision" (Déchirer le coeur de Corinne, ou manquer à la mémoire de son père, c'était une alternative si cruelle, qu'il invoqua mille fois la mort pour y échapper; enfin il fit encore ce qu'il avait fait tant de fois, il recula l'instant de la décision) (322; 472). Procrastination, in the Romantic reading of Hamlet, is indeed a reflection of the character's innate irresolution.

Like Horatio, however, Lord Nelvil is invited to cast aside his debilitating melancholy and renounce the law of the father. For both protagonists, the alternative consists in allowing their lives to be reshaped 
through union with a fascinating foreign woman: Glorvina in The Wild Irish Girl, Corinne in Staël's novel. What is offered here is not the traditional alternative that presents itself to Hamlet, that is, violent action, revenge, and tragic glory. For Hamlet, action ultimately implies carrying out the revenge ordered by the Ghost; Owenson's and Staël's protagonists, by contrast, are invited to reject the destructive terms of the logic imposed by previous generations and to take up the challenge raised by heroines who also assume Shakespearean identities. Whereas Romantic Hamlets remain utterly paralyzed by their inability to execute the Ghost's command, Horatio and Lord Nelvil are given the possibility of charting a new course of action outside their fathers' spheres of influence.

Like Hamlet, The Wild Irish Girl is a tale of usurpation and revenge, and it could easily have ended in tragedy: Horatio might have become an agent in or a casualty of the smoldering feud between his own English family and that of his Irish hosts. Glorvina's father is indeed the last male heir of a Milesian family whose lands were usurped by an English soldier from whom Horatio is descended. The Castle of Inismore is reportedly haunted by the ghost of the dispossessed Irish owner of the lands that now belong to Horatio's English father: "The father of the present Prince built this house, because his Lady . . . took a dislike to the castle; the story going that it [the castle] was haunted by the murdered Prince" (38). Glorvina's father, the present Prince of Inismore, seems to merge with that ghost in his desolate old age: "The fine old Prince not having as much as a shed to shelter his grey hairs under, was forced to fit up part of the old ruined castle, and open those rooms which it has been said were haunted" (39). Such intimations of the supernatural are part of what makes The Wild Irish Girl a gothic novel of sorts, as some critics have noted. ${ }^{18}$ But this gothic dimension is reinforced and perhaps subsumed by the novel's Hamletic subtext. Eighteenthcentury gothic owed considerable debts to the Shakespearean supernatural and to Hamlet in particular: from Horace Walpole to Ann Radcliffe and beyond, Shakespearean ghosts abound in gothic fiction. ${ }^{19}$

18 See, e.g., Bridget Matthews-Kane, "Gothic Excess and Political Anxiety: Lady Morgan's The Wild Irish Girl," Gothic Studies 5, no. 2 (2003): 7-19.

${ }^{19}$ See John Drakakis and Dale Townshend, eds., Gothic Shakespeares (London: Routledge, 2008); and Christy Desmet and Anne Williams, eds., Shakespearean Gothic (Cardiff: University of Wales Press, 2009). 
A version of Hamlet's Ghost also haunts The Wild Irish Girl, where it speaks for old, unresolved Irish grievances. Gothic echoes of Hamlet in Owenson's novel thus confirm readings of Irish gothic as a literary form that expresses doubts about the legitimacy of the Williamite settlement and of English confiscations of Irish land. ${ }^{20}$

The outcome of The Wild Irish Girl, however, is arguably comic, not tragic. ${ }^{21}$ If there is a "consummation devoutly to be wished" — the text quotes the line from Hamlet's "To be, or not to be" soliloquy twice (84, $25^{\mathrm{O}}$ ) - it is neither the oblivion of death nor the fulfillment of revenge but a romantic union with Glorvina, "this family alliance being prophetically typical of a national unity of interests and affections between those who may be facti[ti] ously severe[d], but who are naturally allied" $\left(25^{\circ}\right)$. This union, however, requires an active interest in and respect for Ireland, as the English reader is indirectly invited to "lend your own individual efforts towards the consummation of an event so devoutly to be wished by every liberal mind, by every benevolent heart" (250). Owenson's marriage plot not only rouses Horatio out of his torpor but also thwarts the novel's tragic potential, thanks to the figure of a transformed, empowered Ophelia. Unlike the oversensitive, mad, and eventually dead icon whom the Romantics aestheticized, Owenson's version of Ophelia is ultimately a resilient young woman of no mean achievement.

Indeed, Glorvina is a powerful rebuttal of the Romantic stereotyping of Ophelia as a frail, passive victim unhinged by circumstances. If Horatio's Hamlet is both weak and inauthentic, Glorvina's Ophelia is in the end hardly the Romantic image of "a girl who feels too much, who drowns in feeling. The Romantic critics seem to have felt that the less said about Ophelia, the better; the point was to look at her."22 Glor-

${ }^{20}$ See, e.g., Luke Gibbons, Gaelic Gothic: Race, Colonization, and Irish Culture (Galway: Arlen House, 2004), 19.

21 Some critics, more skeptical about the projected marriage between Horatio and Glorvina, stress the colonial power relations at work behind their union. See, e.g., Julia Anne Miller, "Acts of Union: Family Violence and National Courtship in Maria Edgeworth's The Absentee and Sydney Owenson's The Wild Irish Girl," in Border Crossings: Irish Women Writers and National Identities, ed. Kathryn Kirkpatrick (Tuscaloosa: University of Alabama Press, 2000), 13-37.

22 Elaine Showalter, "Repressing Ophelia: Women, Madness, and the Responsibilities of Feminist Criticism," in Shakespeare and the Question of Theory, ed. Patricia Parker and Geoffrey Hartman (New York: Methuen, 1985), 83. 
vina wears "a robe of vestal white" that, besides its obvious overtones of purity, should be seen in opposition to Horatio's Hamletic "customary suit of solemn black" $(48,67)$ : the visual contrast between Ophelia's white and Hamlet's black had become traditional in stagings of the play. ${ }^{23}$ Like Ophelia, Glorvina is very knowledgeable about flowers and hands out various specimens as signs of affection:

"See," she added, springing lightly forward, and culling a plant which grew from the mountain's side- - "see this little blossom which they call here, 'yellow lady's bed-straw,' and which you, as a botanist, will better recognize as the Galicens borum; it communicates a beautiful yellow; as does the Lichen juniperinus, or 'cypress moss,' which you brought me yesterday; and I think the resida Luteola, or 'yellow weed,' surpasses them all." (94)

After a minute's pause — "Take the rose," said Glorvina, endeavouring to extricate the precious hand which presented it- "Take it; it is the first of the season! My father has had his snowdrop-the confessor his violet—and it is but just you should have your rose." (141)

Glorvina's botanical knowledge, though, points to her depth of intellect rather than serving, in Laertes's words, as a confirmation of Ophelia's madness:

Ophelia: There's rosemary, that's for remembrance-pray you, love, remember. And there is pansies, that's for thoughts.

Laertes: A document in madness: thoughts and remembrance fitted. $(4 \cdot 5 \cdot 173-75)$

Glorvina may well strike Horatio as "the most sentient of all created beings" (81), but her education mitigates her sheer sensibility: a reinvigorated Horatio sees to it that she develops into a "rational, and also benevolent being; for I have always conceived an informed, intelligent and enlightened mind, to be the best security for a good heart" (79). Through their interest in each other, Horatio and Glorvina escape from the dangers of excessive melancholy and sensibility, respectively, and rescue melancholy itself from the dead end of Romantic Hamletism.

Glorvina also resembles Ophelia in that she briefly goes mad when her father dies, accuses others of killing him, and sings plaintively:

${ }^{23}$ See Martha C. Ronk, "Representations of Ophelia," Criticism 36, no. 1 (1994): 24. 
At that moment Glorvina appeared; she had rushed from the arms of her attendants, her strength was resistless, for it was the energy of madness; her senses were fled. . . . she glided up the hall to the bier, and gazing earnestly on her father, smiled sadly, and waved her hand; then kissing his cheek, she threw her veil over his face, and putting her finger on her lip, as if to impose silence, softly exclaimed, "Hush! he does not suffer now! he sleeps! it was I who lulled him to repose with the song his heart loves!" and then kneeling beside him, in a voice scarcely human, she breathed out a soul-rending air she had been accustomed to sing to her father from her earliest infancy. . . . Abruptly breaking off her plaintive strain, she drew the veil from her father's face, and suddenly averting her gaze from his livid features, it wandered from the Earl of M. to his son; while with a piercing shriek she exclaimed, - "Which of you murdered my father?" (242)

Unlike Ophelia, Glorvina is not overcome by her madness. She recovers and comes to terms with her loss as her "sorrow is mellowed by reason" and transformed into "a tender and not ungracious melancholy" (245): not the hyperbolic, self-indulgent, Romantic melancholy that a Hamletlike Horatio has cultivated early in the novel but one in keeping with Owenson's enlightened version of sensibility, ${ }^{24}$ going back to the more subdued form of melancholy found in the eighteenth-century literature of sentiment. That version of melancholy, unlike Romantic Hamletism, did not imply a solipsistic withdrawal into a world of inner thoughts but was a source of sympathy for others. Its clearest expression was probably given by Radcliffe: "that delicious melancholy which no person, who had felt it once, would resign for the gayest pleasures," a sentiment that can "waken our best and purest feelings, disposing us to benevolence, pity, and friendship." 25

${ }^{24}$ For a discussion of Morgan's attachment to a pre-Romantic concept of sensibility see Christopher Nagle, "From Owenson to Morgan: History, Sensibility, and the Vagaries of Reception in The Wild Irish Girl," in Anglo-Irish Identities, I57I-I845, ed. David A. Valone and Jill Marie Bradbury (Lewisburg, PA: Bucknell University Press, 2008), 199-219.

25 Ann Radcliffe, The Mysteries of Udolpho, ed. Bonamy Dobrée (Oxford: Oxford University Press, 1998), 46. Owenson's "tender" melancholy is also comparable to the sentiment to which Radcliffe applies the term when she envisions the female actress Sarah Siddons as her ideal Hamlet: "She would more fully preserve the tender and refined melancholy, the deep sensibility, which are the peculiar charm of Hamlet" ("On the Supernatural in Poetry. By the Late Mrs. Radcliffe," New Monthly Magazine 16, no. 1 [1826]: 147). 
Corinne, perhaps an even more formidable and certainly a more independent woman than Glorvina, initially appears to exert on Lord Nelvil an effect similar to the one experienced by Horatio: as the young lord points out, "It is by raising me above myself, Corinne, that you dispel my natural melancholy" (C'est en m'élevant au-dessus de moimême, Corinne, que vous dissipez ma mélancolie naturelle) (204; 308). With Corinne as his guide, Lord Nelvil learns to do justice to Italy's potential and to discover the sources of Italian backwardness in political fragmentation and institutional oppression, just as Owenson's Horatio is taught by Glorvina to look at Ireland with fresh eyes. Unlike Glorvina, however, Corinne will fail to cure Lord Nelvil of his melancholy condition; she will instead fall prey to it herself, with tragic consequences.

In Staël's multinational novel, melancholy is partly a sign of national character: the moody Englishman had become a stock character in the French literary imagination during the eighteenth century. Although he is nominally Scottish, "Lord Nelvil . . p plays the role of the melancholic Englishman to perfection." 26 For French liberal commentators in the age of Enlightenment, English melancholy had not yet acquired the modern meaning that developed during the Romantic period. Instead, as a feature of the national mind, melancholy made Englishmen pensive, moody, restive, but also, consequently, inclined to take an interest in public affairs and to defend personal freedom through politics (Gidal, "Civic Melancholy," 25-26). It is apparent in Corinne that Staël herself has inherited this eighteenth-century view of English melancholy, but she simultaneously registers its contemporary transformation into Romantic weltschmerz, a pathology of the alienated individual rather than a civic virtue.

Melancholy plays an ambivalent role in Staël's work, its very nature shifting between residual and emerging meanings. Staël sometimes relied on older definitions, designating a generally reflective temper or disposition and linked to humoral theory and national stereotyping. But she also sensed that a new version of melancholy was becoming the Romantic mal du siècle (Garry-Boussel, 86). Biographical readings of her work stress her own propensity to melancholy and see it, then, as a

${ }^{26}$ See Eric Gidal, "Civic Melancholy: English Gloom and French Enlightenment," Eighteenth-Century Studies 37, no. 1 (2003): 30. 
model for Corinne's depression. As a woman with a tormented love life and as an isolated liberal intellectual threatened first by revolutionary excesses and later by Napoléon's suspicions, Staël had enough reasons to fall victim to the weltschmerz of her contemporaries. Yet Corinne is less a biography in disguise than an exploration - sympathetic and critical by turns - of the emerging phenomenon of Romantic melancholy.

In De la littérature Staël adapts eighteenth-century French views of English melancholy by describing it as characteristic of northern people and their literature, which she spends much time defending against the strictures of French neoclassicism. But in the same pages melancholy is also seen as part of what made northern people despise "the spirit of the Enlightenment" (l'esprit des lumières), to which Staël herself remained profoundly attached. ${ }^{27}$ Staël's ambivalence toward melancholy also informs her portrayal of Lord Nelvil in Corinne, where Scottishness and Englishness blend into a "northern" type. Beyond the "northern" cast of his mind, Lord Nelvil also manifests the transition of melancholy from an English civic virtue into a Romantic disposition for which Hamletism is another name. At first his nominal Scottishness seems to associate his northern melancholy with an antiquarian interest in national culture. Corinne thus invokes Ossian in their conversations to bolster Lord Nelvil's interest in the Italian culture that she embodies, as when she claims that the "best and most elegant translation of Ossian is by Cesarotti" (Cesarotti a fait la meilleure et la plus élégante traduction d'Ossian qu'il y ait) (109; 174) or that the poetry of the Dalmatians "is a little like Ossian, though they live in the South" (ressemble un peu à celle d'Ossian, bien qu'ils soient habitants du midi) $(291 ; 429) .28$

In Lord Nelvil's mind, however, Ossian is associated only with the gloom of his Hamlet-like funereal obsessions: "Our Ossian places only regrets and funeral chants beside the grave" (Notre Ossian ne place à côté de la tombe que les regrets et les chants funèbres) $(61 ; 106)$.

27 Germaine de Staël, De la littérature considérée dans ses rapports avec les institutions sociales, ed. Paul Van Tieghem, 2 vols. (Paris: Minard, 1959), 1:133.

28 For a discussion of Scottish and Italian cultural nationalism in Corinne see Catherine Jones, "Madame de Staël and Scotland: Corinne, Ossian, and the Science of Nations," Romanticism 15, no. 3 (2009): 239-53. 
The more extreme, pathological manifestations of his melancholy keep him from casting off his obsession with his dead father and breaking the spell that his promise to that father has put on his mind. While Owenson's Horatio forgets his melancholy as he becomes absorbed in the study of Ireland, Lord Nelvil's melancholy eventually makes him turn away from Corinne and Italy. The positive aspects of his national disposition gradually yield to a pathology that prevents Corinne from raising him above himself. Instead of making him identify with a resurgent Italy, melancholy causes Lord Nelvil to withdraw into an exclusive English domesticity: unable ever to make Corinne an offer of marriage, he will marry English Lucile Edgermond instead. The only possible consummation of the growing but undesirable attachment between Corinne and Lord Nelvil is Corinne's death, as she herself already senses during her improvisation at Cape Miseno:

"What happens when destiny separates us from the man who has the secret of our soul and gave us the life of the heart, celestial life? What happens when absence or death isolates a woman on the earth? She languishes, she falls! . . ordinary people take for madness the malady of the soul which can no longer breathe enough air, enough emotion, enough hope in this world." (237)

[“Qu'arrive-t-il quand la destinée nous sépare de celui qui avait le secret de notre âme, et nous avait donné la vie du coeur, la vie céleste? Qu'arrive-t-il quand l'absence ou la mort isolent une femme sur la terre? Elle languit, elle tombe . . et le vulgaire prend pour de la folie ce malaise d'une âme qui ne respire pas dans ce monde assez d'air, assez d'enthousiasme, assez d'espoir."] (353-54)

Corinne - who is half Italian, half English — in fact becomes infected by Lord Nelvil's melancholy; she takes it on herself instead of freeing him from it. After her improvisation, "the English who had heard Corinne were filled with admiration for her. They were delighted to see melancholy feelings expressed in this way with Italian imagination" (les Anglais qui avaient entendu Corinne étaient pénétrés d'admiration pour elle. Ils étaient ravis de voir ainsi les sentiments mélancoliques exprimés avec l'imagination italienne) (238; 355).

For all its aesthetic appeal, the melancholy with which Lord Nelvil infects Corinne is a disease - in that sense, it bears witness to the Romantic pathologization of melancholy, which in turn led to the 
Freudian analyses of Hamlet. ${ }^{29}$ As with Hamlet, Freudian readings of Corinne show how mourning and melancholia go hand in hand to explain Lord Nelvil's inability to be freed by Corinne. Abandoned by him and infused with his melancholy, a broken Corinne relinquishes her role as an Italian poet and follows Lord Nelvil incognito in England, where she also revisits the tomb of her father. Her melancholy thus confirms her defeat by the very structures of patriarchy that she had initially unsettled:

While the sons initially experience the Father's death as the imperative to reproduce the Law that authorizes their own position, daughters experience it as a release from the Law that their own productivity transgresses. Ultimately, however, the distinction between these gendered reactions disappears. The inability to bury the dead Father drags son and daughter alike into the melancholy abyss. ${ }^{30}$

If melancholy is effectively genderless in its capacity to affect the minds of Corinne and Lord Nelvil, its results confirm rather than undermine patriarchal domination: ${ }^{31}$ as a "feminized man," the melancholy Lord Nelvil is eventually exposed "not as a sad exception to patriarchal rule but as the latest incarnation of the law of the fathers" (Waller, $5^{8}$ ). Not only does he return to England to fulfill his father's domestic wishes, but he enlists in a regiment to defend Britain in its impending war with revolutionary France.

When Corinne succumbs to the soul sickness that first afflicted her lover, she takes on the overtones of a dejected Ophelia. Shadowing Lord Nelvil back in what is also her fatherland (i.e., the England of her own father), Corinne ends up roaming near the castle of the

${ }^{29}$ Gidal argues that the Romantic insistence on the psychopathological nature of Hamlet's melancholy "lays the groundwork for . . . the more famous readings of Freud, Jones, and Lacan, and helps precipitate the literary reconfiguration of melancholy from a temperamental nexus of cultural mores, social institutions, and historical conditions to a self-isolating disposition of a wounded sensibility” ("Gross and Barbarous Composition,'” 256).

30 Margaret Cohen, "Melancholia, Mania, and the Reproduction of the Dead Father," in The Novel's Seductions: Staël's “Corinne” in Critical Inquiry, ed. Karyna Szmurlo (Lewisburg, PA: Bucknell University Press, 1999), 113.

31 See Anne C. Vila, “Ambiguous Beings': Marginality, Melancholy, and the Femme Savante," in Women, Gender, and Enlightenment, ed. Sarah Knott and Barbara Taylor (Houndmills: Palgrave Macmillan, 2005), 53-69. 
Edgermonds, where a ball is given in Lord Nelvil's honor. In the one scene from the novel that refers explicitly to Hamlet, Corinne blends the roles of the Ghost and of the desolate Ophelia contemplating suicide by drowning:

As Corinne walked on, she found herself near the river. There she could hear both the festive music and the sound of the water. . . As in the tragedy of Hamlet, it was as if ghosts were wandering round the palace where festivities were taking place. Corinne, unhappy, alone, and forsaken, had only one step to take to plunge into eternal forgetfulness. $(341)$

[Corinne en marchant se trouva près de la rivière; elle entendit là tout à la fois la musique de la fête et le murmure des eaux. ... On eût dit que dans ces lieux, comme dans la tragédie de Hamlet, les ombres erraient autour du palais où se donnaient les festins. L'infortunée Corinne, seule, abandonnée, n'avait qu'un pas à faire pour se plonger dans l'éternel oubli.] (499)

By associating Corinne with Ophelia, Staël departs from the tendency of French Romantic women writers to shun a character "prized by nineteenth-century French male writers" for its embodiment of the helpless, oversensitive female heroine. ${ }^{32}$ Staël's view of Ophelia, however, is quite different from the stereotype peddled in male representations. In De la littérature she suggests that Ophelia deserves to be put on a par with Hamlet and Lear as examples of Shakespeare's masterly representation of moral suffering and madness: "Hamlet, Ophelia, and King Lear . . possess the same quality of distraction. . . Madness as Shakespeare depicts it is the most sublime representation of foundering moral nature" (Hamlet, Ophélie, le roi Lear . . ont un même caractère d'égarement. . . . La folie, telle qu'elle est peinte dans Shakespeare, est le plus beau tableau du naufrage de la nature morale) $(205-6)$. In Corinne Staël's version of Ophelia actually upstages the novel's Hamlet: not only does the scene outside the Edgermonds' castle implicitly recast

32 See Aimée Boutin, "Shakespeare, Women, and French Romanticism," $M L Q$ 65 , no. 4 (2004): 529 . For a comprehensive study of the uses of Ophelia in (male) French nineteenth-century culture see James M. Vest, "Romantic Ophelias," in The French Face of Ophelia from Belleforest to Baudelaire (Lanham, MD: University Press of America, 1989), 109-6o. Vest does mention Staël's comments on Ophelia in De la littérature, but he does not consider Corinne. 
Lord Nelvil as a guilty Claudius (it is his future union that is celebrated there), but Corinne's melancholy suffering proves more intense and tragic than that of her erstwhile lover. The likening of Corinne to a suicidal Ophelia foreshadows contemporary feminist readings of the play in their insistence that Ophelia's melancholy is not merely derivative of Hamlet's or inferior to it: "By sharing his own existential anxiety with Ophelia during 'to be or not to be,' Hamlet infects her with it, but also indirectly shows to us that she is very much 'capable of her own distress.' "33 Corinne's sacrifice through melancholy becomes the moral lesson of the novel. Her posthumous legacy is a reproof to those who, like Lord Nelvil, cannot be raised above their own selves and who follow Romantic Hamlets in making melancholy the mode of an existence that perpetuates itself through passivity and vacillation. ${ }^{34}$ Corinne's affliction is also more destructive than the "tender and not ungracious melancholy" that Owenson recommends in The Wild Irish Girl. As in Owenson's novel, however, this version of the condition is also an alternative and a rebuke to the more egocentric and ineffectual melancholy that grips the male protagonist.

In the end Corinne is not as easily pushed to the margins of the plot as Ophelia is in Hamlet. The dying Corinne finally becomes the ghost haunting Lord Nelvil: the specter of his own failure to rise above Hamletic melancholy, to choose unconventional love and Italy instead of England, duty, and domesticity. Her own words invite a comparison with the ghost who "fades on the crowing of the cock" (1.1.162): "It is as if I were a ghost who still wants to remain on earth when the sun's rays, when the approach of the living, force her to disappear"

\footnotetext{
33 Madga Romanska, "Ontology and Eroticism: Two Bodies of Ophelia," Women's Studies 34, no. 6 (2005): 492 .

34 This reading confirms Jean Starobinski's remarks on the nature of melancholy in Staël's work: "Melancholy, which Staël discusses so often and nearly elevates to a prime criterion of great modern literature, need not be understood as a morose mood of uncertain and repressed passions; it is the condition of the soul of one who leads a posthumous existence beyond the final extinction of his desire and personal life" (La mélancolie, dont [Staël] parle si souvent et dont elle fait presque la condition principale de la grande littérature moderne, ne doit pas s'entendre comme le climat morose des passions incertaines et réprimées; c'est l'état d'âme de celui qui mène une existence posthume au-delà de son désir et de sa vie personnelle à tout jamais consumés) (Table d'orientation: L'auteur et son autorité [Lausanne: Âge d'Homme, 1989], 87).
} 
(on dirait que je suis une ombre qui veut encore rester sur la terre, quand les rayons du jour, quand l'approche des vivants, la forcent à disparaître) $\left(35^{8} ; 5^{22}\right)$. Corinne remains admirably tragic in death and beyond it. Juliet was the role she played in front of Lord Nelvil, and of Shakespeare's tragic women, Juliet is among the least passive: another rebel against patriarchal laws who is eventually defeated, she nevertheless remains in command of her destiny to the very end. ${ }^{35}$ As a tragic heroine, then, Corinne remains more formidable than the Romantics' helpless Ophelia; she may be unable to overcome the figure of the dead father, but, in her ghostlike capacity to haunt Lord Nelvil, she replaces that father at the end of the novel. While Staël's Hamlet survives, her tragic Ophelia supplants the Ghost whose command has resulted in her death; Corinne's tragic melancholy posthumously eclipses Lord Nelvil's Romantic predicament.

Owenson's and Staël's novels thus begin with a focus on Hamletic melancholy and end up exploring new, potentially empowering roles for Shakespearean heroines. That Owenson is more optimistic about these possibilities than Staël is confirmed by the different versions of melancholy that beset their heroines in the final stages of their novels. But both authors sought to question and overcome the cult of Hamlet that was taking root in Europe after revolutionary failures and disillusions: in English culture, partly through the reinterpretation of Hamlet that Owenson could witness at first hand; in French culture, through a version best defined by Châteaubriand's René; and in German culture, through the versions of Hamlet that Goethe, August Schlegel, and others also made familiar to Staël. While those postrevolutionary Hamlets withdrew from the world of action and impossible hopes into a world of melancholy contemplation, Owenson and Staël made it clear that the revolutionary debacle did not put an end to legitimate liberal

35 By its association with Juliet's suicide, Corinne's death also differs from a Romantic and Hamletic infatuation with the idea of suicide. As Florence Lotterie points out, Staël generally denounced “'sentimental' exaltation-and here it is necessary to give the adjective a pejorative sense-common among the disciples who misunderstood Werther" (l'exaltation "sentimentale" — et il faut ici donner à l'adjectif, de création récente, un sens péjoratif-des disciples d'un Werther mal compris) (“Corinne, un roman des 'âmes sensibles'?" in Madame de Staël: Corinne ou l'Italie, ed. Jean-Pierre Perchellet [Paris: Klincksieck, 1999], 105). 
aspirations in Europe; on the contrary, they survived in peripheral contexts like Italy and Ireland or in the promotion of women's rights. Both authors challenged the melancholy, apathetic male intellectual to resist the specious consolation of the Hamletic pose and to consider what their own enlightened and feminist versions of sensibility and melancholy still had to offer. Instead of colluding with the transformation of melancholy into the inhibiting weltschmerz of the Romantic intellectual, both writers highlighted the dangers inherent in that process. ${ }^{36}$

Despite Staël's and Owenson's early critiques, Hamletism developed apace in Europe in the decades that followed, leading ultimately to Stéphane Mallarmé's melancholy and solipsistic intellectual "reading in the book of himself" (lisant au livre de lui-même). ${ }^{37}$ Hamletism occasionally came in for criticism: in her later national tales Owenson associated the figure of the listless, jaded English aristocrat with a melancholy Hamlet. ${ }^{38}$ The most vocal criticisms, however, were made by male intellectuals who attacked modern Hamlets for their lack of heroism. In 1844 the German radical Ferdinand Freiligrath famously complained that "Germany is Hamlet!" (Deutschland ist Hamlet!): too passive, intellectual, and melancholy to take up arms in the cause of political unification and liberation. Freiligrath berated the German intellectuals' literary icon for his indecisiveness, his dreaminess ("Er sinnt und träumt und weiß nicht Rat"), his lack of courage ("Zu einer frischen, mut'gen Tat / Fehlt ihm die frische, mut'ge Seele”), and his preference

36 This analysis of Hamletic melancholy in Corinne also confirms Lotterie's contention that "Madame de Staël, for her part, always opposed this feeling of disillusionment, persuaded that the new society would derive its force solely from the rejection of disenchantment and the acceptance of a different sensibility, more melancholy but not totally nonexistent" (Mme de Staël s'est pour sa part toujours élevée contre ce sentiment de désillusion, persuadée que la société nouvelle ne devrait sa force qu'au refus du désenchantement et à l'acceptation d'une sensibilité différente, plus mélancolique, mais non pas totalement inexistante) (106).

37 Stéphane Mallarmé, "Divagations, grands faits divers," in Oeuvres complètes, ed. Henri Mondor and G. Jean-Aubry (Paris: Gallimard, 1945), 275.

38 In Owenson's Princess; or, The Béguine (London: Bentley, 1835), the melancholy English aristocrat Sir Frederick Mottram tells his friend Horace that neither his help nor that of a physician will avail: "I have that within, which passes their and your skill" (154); cf. Hamlet's "I have that within, which passeth show" (1.2.85). For a comparison with Horatio's melancholy in The Wild Irish Girl see Raphaël Ingelbien, "Paradoxes of National Liberation: Lady Morgan, O'Connellism, and the Belgian Revolution," ÉireIreland 42, nos. 3-4 (2007): 110-11. 
for thought over action ("Sein bestes Tun ist eben Denken"). For the Young Germany firebrand, however, the alternative was violence: the German Hamlet was urged to draw his sword ("Noch ist es Zeit—drein mit dem Schwert") to unify Germany through revolution. ${ }^{39}$

Owenson and Staël also criticized Hamletism in defense of nationalist causes, yet they made no calls to arms; rather, they invited the melancholy intellectuals of leading nations to look beyond the political stalemates of their own societies and to help marginalized nations achieve recognition. This was in keeping both with their liberal politics, which were less revolutionary than Freiligrath's, and with their feminism, which made them as suspicious of old-style male heroism as of its modern Hamletic antithesis. At a time when a new, largely masculine Romantic culture was relegating women to the private sphere, Owenson and Staël rejected both vengeful, forbidding paternal ghosts and their incapacitated sons and tried to assert their own enlightened, feminist ideals through the voices of Shakespearean daughters instead. ${ }^{40}$ Ultimately, the solutions they tentatively looked for were best articulated through heroines who could act as foils to the weltschmerz of Romantic Hamlets, rather than through an exclusive focus on Hamlet himself.

39 Ferdinand Freiligrath, "Hamlet," in Freiligraths Werke, ed. Julius Schwering, vol. 2 (Berlin: Bong, n.d.), 71.

${ }^{40}$ Boutin observes that, with the advent of nineteenth-century Romanticism in Europe, "women, like the [Shakespearean] heroines discussed by male writers, were being pulled into the private sphere" (529). In comparing the gender politics of Corinne with those of The Wild Irish Girl, Caroline Franklin also stresses the authors' predicament: "The exclusion of liberal nineteenth-century salonnières and women writers from political discourse in France and Britain intensified their recourse to literature, as the only permissible intervention in the private sphere" ("Romantic Patriotism as Feminist Critique of Empire: Helen Maria Williams, Sydney Owenson and Germaine de Staël," in Knott and Taylor, 555). Those literary interventions, however, were increasingly disputed by male critics and writers; see Morin. 
Raphaël Ingelbien is senior lecturer in English and comparative literature at the University of Leuven. His research focuses on the European contexts of nineteenthcentury Irish writing. He has published articles on Irish literature in Éire-Ireland, New Hibernia Review, and various collections of essays.

Benedicte Seynhaeve holds an MA in Western literature from the University of Leuven, where she wrote a thesis on The Wild Irish Girl. She teaches Dutch to international students at the same university. 
